Egyptian Journal of Aquatic Biology \& Fisheries

Zoology Department, Faculty of Science,

Ain Shams University, Cairo, Egypt.

ISSN $1110-6131$

Vol. 25(3): 883 - 899 (2021)

www.ejabf.journals.ekb.eg

\title{
Biochemical, Histopathological, and Genetic Impacts of River Nile Pollutants on the Nile tilapia (Oreochromis niloticus)
}

\section{Anas A. Heiba ${ }^{1^{*}}$, Amal M. Yacoub ${ }^{2 \& 4}$, Ebrahim A. Sabra ${ }^{1}$, Reham M. Abd El-Azeem ${ }^{3}$, Medhat H. Hashem ${ }^{1}$}

1. Animal Biotechnology Department, Genetic Engineering and Biotechnology Research Institute

(GEBRI), University of Sadat City (USC), Sadat City, Egypt.

2. National Institute of Oceanography and Fisheries, Cairo, Egypt.

3. Environmental Biotechnology Department, GEBRI, USC, Sadat City, Egypt.

4. Faculty of Science, Taif University

*Corresponding Author: anas-heaba@ hotmail.com

\begin{abstract}
ARTICLE INFO Article History:

Received: April 17, 2021

Accepted: June 2, 2021

Online: June 30, 2021

Keywords:

Pollutants,

Biochemical,

Histopathological,

Genetic,

SSR (Simple sequence

repeats),

Oreochromis niloticus,

River Nile.

\section{ABSTRACT}

Water pollution is one of the most principal environmental and public health problems in the River Nile. In the present study, aims were directed to evaluate the biochemical, histopathological, and genetic effects of ElRahawy Drain pollutants on the Nile tilapia (Oreochromis niloticus). Hence, during the summer of 2018 and winter 2019, fish samples were collected from two locations (upstream and downstream) of El-Rahawy drain in the River Nile at the Rosetta Branch. Biochemical studies (Total Protein, Albumin, Globulin, A/G, total lipids, Cholesterol, AST, and ALT) were carried out for the specimens and important results were revealed. Compared with the fish caught from the upstream, a deterioration was detected in the health status of the downstream- fish; displaying more extreme histopathological and molecular variations. Using SSR (simple sequence repeats) to detect the molecular effects of water pollutants on $O$. niloticus, molecular markers indicated genetic differences in fish samples from the same sex in the different studied locations. Consequently, to prevent disease outbreaks and aquatic ecosystem disturbances, the Rosetta Branch is recommended to have an intensive water-quality monitoring program, and wastewater treatment as well.
\end{abstract}

\section{INTRODUCTION}

All over the world, freshwater resources such as rivers are polluted with a variety of solid and liquid wastes. In Egypt, the River Nile has become polluted due to the discharge of untreated waste, dumping of industrial effluents, and run-offs from agricultural fields, making it a model for a polluted ecosystem to assess biomarker responses in fish (Osman 2012; Hashem et al., 2020a). The River Nile is Egypt's most important source of water. It bifurcates at a distance of $25 \mathrm{~km}$ (north of Cairo) into the Rosetta and Damietta branches forming a delta (Abdel-Satar et al., 2017). Rosetta 
Branch is about 225 kilometers long with an average depth of 2.0-2.3 meters. Agricultural, commercial, and domestic wastewaters, as well as anthropogenic activities, all contribute to a high microbial load on the Rosetta Branch in addition to the organic and inorganic pollutants (Othman et al., 2020). Therefore, serious negative impacts on the branch environment have been detected (Hashem et al., 2020a).

The Nile tilapia is the sixth most cultured fish in the world (Reantaso, 2017; Hashem et al., 2020b). It can be used to estimate the Nile pollutants and is one of the most major biomonitors for water pollution (Hamdoon et al., 2002a, b; Begum, 2004). The pollutants directly enter the River Nile fish through the gills or the intestines. Then, through the bloodstream, pollutants are distributed throughout the body, where blood cells are the first receptors (Sadauskas-Henrique et al., 2011). Remarkably, blood biomarkers have been over used in fisheries science because being crucial in toxicological research, environmental monitoring, and predicting fish health conditions. (Bitten-Court et al., 2003). As a result, fish blood shows observable physiological changes faster than any other physiological evaluation parameter (Ezeri et al., 2004). It also reacts to changes in other tissues as a result of pollution exposure (Ruas et al., 2008). Since blood parameters react to low doses of contaminants, hematological and biochemical variables have recently emerged as promising biomarkers for measuring the effects of aquatic pollution in fish. Blood parameters are critical in diagnosing the structural and functional state of fish exposed to environmental contaminants because they are considered good physiological biomarkers of the entire body (Seriani et al., 2011). Hematological and biochemical variables' responses to environmental stressors are usually unspecific. Nonetheless, by indicating the general physiology and health status of fish, they can provide useful information in impact assessment studies (Beyer et al., 1996).

The muscular system makes up the majority of a teleost's body. Locomotion, synchronized movement of skeletal components, blood pumping, and peristaltic constriction of visceral organs and their associated structures are some of their roles in the overall body (Saad $\boldsymbol{e t}$ al., 2012). The epidermis of skin has recently been shown to contain naturally bacteriolytic substances as well as a constantly responding immune system, where, the affected epidermis losing its protective function as well as its osmotic barrier ability (Kadry et al., 2015).

Genome identification and selection have progressed rapidly with PCR technology help. A large number of markers that require only a small quantity of DNA have been developed. Each marker method has its advantages and disadvantages (Shehata et al., 2009). Molecular markers such as inter simple sequence repeats (ISSR) and simple sequence repeats (SSR) markers are vital tools for monitoring fish populations (Rashed $\boldsymbol{e t}$ al., 2008; Hashem $\boldsymbol{e t}$ al., 2020a) and fish species genetic variability (Saad et al., 2009). The SSR marker is a co-dominant molecular marker that 
can distinguish between homozygotic and heterozygotic samples and also have a large number of alleles.

Hashem et al. (2020a) found that water quality parameters (nutrient salts and heavy metals) were increased at downstream of El-Rahawy Drain in addition to the depletion of dissolved oxygen. Additionally, fish samples showed severe histological and molecular alterations in downstream compared to upstream by using liver tissues and PCR-ISSR markers, respectively.

Thus, the present study aimed to evaluate the biochemical, histopathological (skin and muscles), and genetic effects (by using SSR molecular markers) of El- Rahawy Drain pollutants on the Nile tilapia; Oreochromis niloticus.

\section{MATERIALS AND METHODS}

\section{1- Study area}

The River Nile pollutants are derived from different uncontrolled sources such as industrial wastewater, agricultural drainage, in addition to municipal wastewater (Al-Afify and Abdel-Satar, 2020). Rosetta Branch receives heavy pollutants, untreated municipal and agricultural drainage water, containing a high amount of organic matter and heavy metals from El-Rahawy Drain. To examine the polluted water, fish samples were collected from two locations (upstream and downstream) of El-Rahawy drain at Rosetta Branch of River Nile during the summer of 2018 and winter 2019 (Fig. 1).

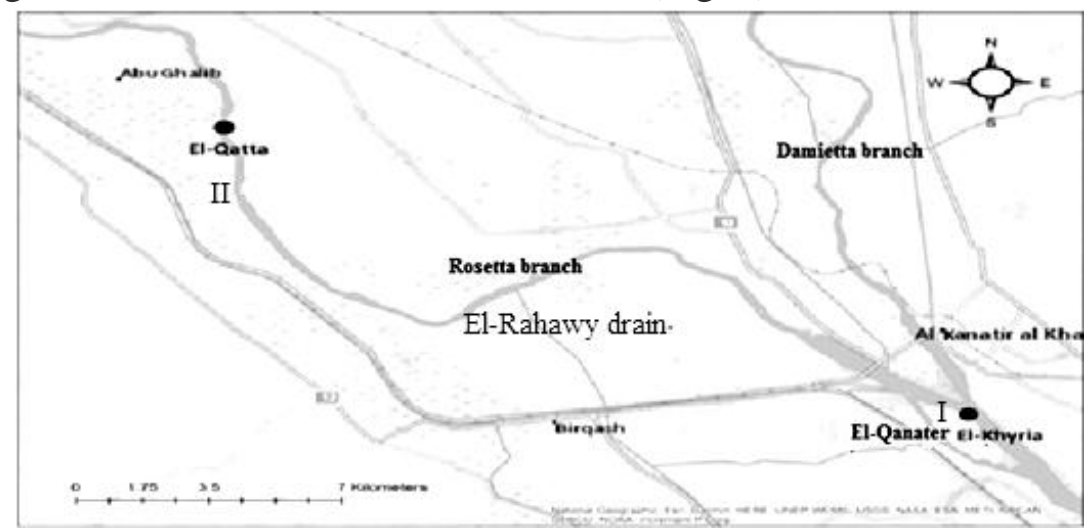

Fig. 1: A map showing the sampling locations in (I) Upstream and (II) Downstream of El-

\section{2- Biochemical studies}

$$
\text { Rahawy drain at Rosetta Branch. }
$$

\subsection{Sampling and preparation of blood serum}

The fish were caught from the selected locations and dried from excess external water with filter paper. The blood samples were taken by cutting the tail of the fish. Blood samples were taken by severance of the caudal peduncle of fish and collected into small sterilized vials. The blood was left to clot and then centrifuged at 3000 r. p. m for 10 minutes to obtain serum. Supernatant serum was obtained using a micropipette model (Labystems K 33071) for biochemical studies. 


\subsection{Blood serum analysis}

\section{- Serum total proteins and albumin}

Kits for the determination of total proteins and albumin (Sigma-Aldrich) were used.

\section{- Globulin content}

The globulin content was obtained by the succeeding equation:

Globulin content $=$ Protein content - Albumin content .

\section{- Serum total lipid and cholesterol}

This was conducted by using serum cholesterol and total lipid Kits (Diamond diagnostic kits, USA).

\section{- Alanine aminotransferase (ALT) and Aspartate aminotransferase (AST)}

For the determination of serum alanine aminotransferase (ALT), aspartate aminotransferase (AST), and creatinine, Spectrum Diagnostics kits, Egypt were used.

\section{3- Histopathological studies:}

Skin and muscle samples obtained from $O$. niloticus were carefully removed then fixed in $10 \%$ formalin, dehydrated in ascending grades of alcohol and cleared in xylene. The fixed tissues were embedded in paraffin wax and sectioned at 5 microns by using Euromex Holland microtome. Sections were stained according to Harris Hematoxylin and Eosin method (Bernet et al., 1999), examined microscopically and photographed by using a microscopic camera.

\section{4- SSR Molecular Markers}

\subsection{DNA extraction}

Fish muscle tissues were used for DNA extraction through a genomic DNA extraction kit (G-Spin) from iNtRON Biotechnology, Inc., Korea. This kit was used for rapid isolation of the total DNA of 20 fish samples from the two locations (10 samples from each, 5 males and 5 females).

\subsection{SSR primers}

Eight SSR marker loci were screened from 20 individuals to detect the differences between the samples from the two studied locations (up and downstream of the drain). The PCR primers that were used are shown in Table (1) as described by Eshel $\boldsymbol{e t}$ al. (2012).

Table 1: Simple Sequence Repeats Markers (SSR) Primers Sequences that were Used with $O$. niloticus Individuals from the Two Studied Locations.

\begin{tabular}{ccc}
\hline Primer & Forward Primer & Reverse Primer \\
\hline $\mathbf{1}$ & TGCTCTCACTGCTGAGCAAA & CGCAAATGTTAGGCCAGAAA \\
\hline $\mathbf{2}$ & AAGACCCGTTCTTCGTCGTC & TTCATTCCACCTGCTCCAAA \\
\hline $\mathbf{3}$ & GTGAGGCAAGTCCGGTTTCT & TGATCCACGGCGTATTGAGT \\
\hline $\mathbf{4}$ & GTGGGCAAAAACAAGCCATT & TGTTTCAGTGTGAACGTGTGTG \\
\hline $\mathbf{5}$ & AGGCCTTTCATCGCTGTTTT & ACCCTGTAGATGAGCGCAAA \\
\hline $\mathbf{6}$ & AAGGGAAAGTGGCTCAGCTC & GTTGCTTCCCCACAGTTTCA \\
\hline $\mathbf{7}$ & AGGAGAAGTCGCAGGTGACA & GGCACAGTTGCCTGGTACAT \\
\hline $\mathbf{8}$ & CGAGCTGCTTTGTTGTCTGA & CGAACCGAAAATGAGAATGC \\
\hline
\end{tabular}




\subsection{PCR amplification conditions}

The PCR conditions were as follows: 5 mins at $94^{\circ} \mathrm{C}$ followed by $60 \mathrm{sec}$ at $94^{\circ} \mathrm{C}$, $45 \mathrm{sec}$ at $55^{\circ} \mathrm{C}$, and $60 \mathrm{sec}$ at $72^{\circ} \mathrm{C}$ for 30 cycles and a final step for $10 \mathrm{mins}$ at $72^{\circ} \mathrm{C}$. PCR products were tested by using 3\% agarose gel electrophoresis. 100 bp DNA ladder plus (iNtRON Biotechnology, Inc. Korea) was used to detect the obtained PCR products. The electrophoresis run was achieved at $75 \mathrm{~V}$ in the DNA electrophoresis unit (Bio-Rad) for 90 mins.

\subsection{Molecular markers data analysis}

The SSR banding patterns were scored as (1) for the appearance band and (0) for the disappearance one. Data matrices were analyzed using the Numerical Taxonomic and Multivariate Analysis System program (NTSYS), version 2.1, Applied Biostatistics Inc. (Rohlf, 2000). Similarity coefficients were applied for dendrogram construction by using the UPGMA (Unweighted Pair Group Method with Arithmetic Average) as well as the SAHN (Sequential Agglomerative Hierarchical Nested Clustering) routine in the NTSYS program.

\section{RESULTS AND DISCUSSION}

\section{Biochemical studies}

The variations of biochemical parameters of the studied $O$. niloticus fish are tabulated in Table (2).

Table 2: Variations of Biochemical Parameters of O.niloticus Fish Collected from Two Different Seasons.

\begin{tabular}{|c|c|c|c|c|c|c|}
\hline \multirow[t]{2}{*}{ Blood Parameter } & \multicolumn{2}{|c|}{ Summer season } & \multicolumn{2}{|c|}{ Winter season } & \multirow{2}{*}{$\begin{array}{c}\text { Ahmed et al. } \\
\text { (2019) }\end{array}$} & \multirow{2}{*}{$\begin{array}{l}\text { Mohamed } \\
\text { et.al. }(2020)\end{array}$} \\
\hline & upstream & Downstream & upstream & Downstream & & \\
\hline Total protein(g/dl) & 3.80 & 2.5 & 3.30 & 2.10 & $3.7-6.3$ & - \\
\hline Albumin (g/dl) & 1.85 & 0.70 & 1.30 & 0.55 & $1.8-1.1$ & - \\
\hline Globulin (g/dl) & 1.95 & 1.50 & 2.00 & 1.55 & - & - \\
\hline ,A/G ratio & 0.92 & 0.46 & 0.65 & 0.35 & - & - \\
\hline Total lipids (mg/dl) & 450.00 & 850.00 & 420.00 & 950.00 & - & - \\
\hline Cholesterol(mg/dl) & 75.50 & 175.50 & 109.25 & 196.60 & 81-189 & $136-202.9$ \\
\hline AST (IU/ml) & 48.00 & 220.00 & 72.50 & 288.00 & $58.6-275$ & $15.2-37.5$ \\
\hline ALT ( IU/ml) & 42.50 & 95.50 & 55.40 & 150.50 & $29-68$ & $14.4-25.4$ \\
\hline
\end{tabular}

Biochemical studies have been used as an indicator of the health status of fish and an important indicator to address the effect of pollutants on fish (Ahmed, 2012; Bayomy et al., 2017; Hashem, 2020a).

\section{Total serum protein (T.S.P.)}

The important function of total serum protein is the maintenance of osmotic balance between the circulating blood and tissue spaces (Ahmed $\boldsymbol{e t}$ al., 2019). The results declared that the T.S.P. has lower values for O. niloticus samples collected from downstream than the upstream as shown in Table (2). Furthermore, those values were lower in winter than in summer. The decrease in the total serum protein in the $O$. niloticus collected from downstream may be due to the changes taking place in serum 
globulin metabolism as a result of different pollutants discharged from El-Rahawy Drain as reported in the study of Tayel et al. (2014).

\section{Total serum albumin (T.S.A.) and Total serum globulin (T.S.GI.)}

The determination of albumin and globulin were taken into consideration in the present investigation, as variation in total serum protein is more or less due to the changes taking place in the serum globulin metabolism as a result of water pollution (Ahmed, 2012). The values of albumin for the selected fish were within the range obtained by Ahmed et al. (2019) as shown in Table (2). The decrease in albumin and globulin for fish living downstream (sewage water) may be explained as a result of the increase in metabolic rate of albumin and globulin due to the decrease or depletion in dissolved oxygen. This explanation agrees with that of Tayel et al. (2008, 2013).

\section{Total serum lipids and Cholesterol}

It was observed that the obtained values of total serum lipids and cholesterol were higher downstream than those recorded upstream (Table 2). In addition, the total serum lipids and cholesterol were recorded high level in winter, where the decrease in flow level of the Nile in winter tends to concentrate the pollutant as ammonia (Ahmed et al., 2019; Mohamed et al., 2020).

\section{Alanine aminotransferase level (ALT) and Aspartate aminotransferase level (AST)}

The lysosomal membranes which are very sensitive to many pathogenic factors are disrupted thus their enzymes are released causing degeneration and vacillation of the cytoplasm of liver cells (Bayomy and Mahmoud, 2007). The aminotransferase alanine and aminotransferase aspartate are two important key enzymes considered as sensitive markers to evaluate hepatocellular damage and some hepatic diseases (Aly et al., 2003). The present data showed that the values of ALT and AST obtained from fish collected from downstream were higher than those obtained from upstream (Table 2). On the other hand, those values recorded the highest level during winter for both locations coinciding with the decrease in the flow level of the Nile. The values of ALT and AST of the $O$. niloticus fish collected from the two studied locations were higher than the ranges obtained in the study of Mohamed et al. (2020). Those results showed a general trend of an increase in ALT and AST activities. Moreover, findings indicated that the pollutants of the Nile water affect the liver cells as evidenced by the alterations that occurred in both AST and ALT activities. Additionally, the increments in the ALT and AST activities could be considered as indicators for liver damage (Ibrahim and Mahmoud, 2005; Bayomy et al., 2017). Furthermore, it may be attributed to sewage wastes of the ElRahawy Drain and increasing of organic pollutants, ammonia, and heavy metals in the River Nile (Ahmed, 2012).

\section{Histopathological studies}

Histopathology is used as a sub-lethal test for evaluating the toxic effect of water pollutants on fish (Yacoub et al., 2020; Tayel et al., 2020; Hashem et al., 2020a). 


\section{Skin and muscles}

Normally, the skin of $O$. niloticus fish is composed of epidermal, dermal, and hypodermal layers. The skin covers the muscles' layer, which is composed chiefly of segmental myomeres. Each myomere is regarded as muscle and its fibers are parallel to the long axis of the body (Tayel $\boldsymbol{e t}$ al., 2018). Skin and muscles of $O$. niloticus, collected from the investigated area, suffered from many pathological alterations.

Morphologically, the skin and muscle of $O$. niloticus fish inhabiting the water of investigated area showed absence of scales and destroyed dorsal fin, especially in specimens collected from the downstream location.

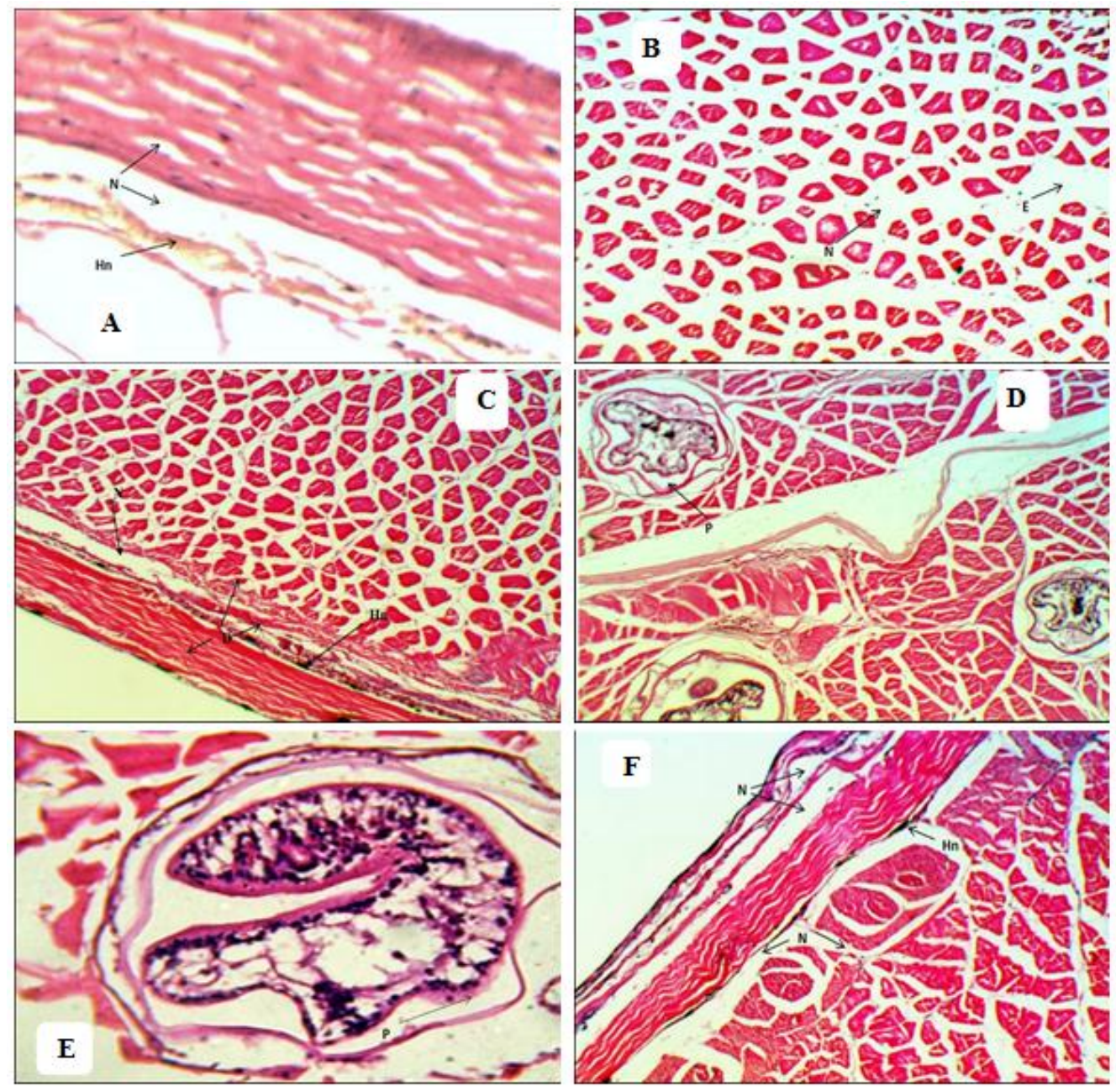

Fig. 2: Vertical Section (V.S.) in Skin and Muscles Sections of $O$ niloticus Collected from

Upstream and Downstream Regions of El-Rahawy Drain Discharge Point at Rosetta Branch. (H\&E) X400. Showing:

a) Necrosis $(\mathrm{N})$ in dermal \& hypodermal layers. Hemosiderin (Hn) in hypodermal layers.

b) Necrosis (N) and edema (E) in the muscles layer.

c) Degeneration (D) in skin \& muscle layers and necrosis (N) \& hemosiderin (Hn) in the connective layer.

d) Parasitic form $(\mathrm{P})$ in the muscle layer.

e) Parasitic form $(\mathrm{P})$ in the muscle layer.

f) Necrosis $(\mathrm{N})$ in epidermal, dermal, hypodermal, and muscle layers. Hemosiderin (Hn) beneath dermal layers. 
Histological alterations of skin and muscles of $O$. niloticus fish collected from the investigated area were summarized in degeneration, necrosis, edema, and hemosiderin accumulation in all skin and muscle layers for samples obtained during winter and summer seasons from upstream and downstream locations but with a severe degree for the sample collected from downstream.Noticeably, samples collected from the downstream location during summer are specified with the occurrence of parasites (Fig. 2). In the present study, the histological alterations in skin and muscle may be attributed to the increasing level of ammonia, trace elements and turbidity in addition to depletion in oxygen concentrations in the surrounding water especially at downstream; forming an observation that matches with that obtained by Ahmed (2012), Bayomy et al. (2017), Hashem et al. (2020a) and Tayel et al. (2020).

\section{Molecular Markers}

Eight primers were used to study the effects of water pollution on SSR loci in the studied samples. The DNA fragments exhibited by the eight primers of SSR (P1-P8) from 20 samples (5 males and 5 females from each location of up and downstream) were separated using 3\% agarose gel electrophoresis and are presented in Fig. (3).

All eight SSR markers loci primers of the 20 studied tilapia samples from the up and downstream of El-Rahawy Drain produced clear amplified fragments of DNA (Fig. 3 ). Most of the loci were polymorphic, with allele numbers that ranged from 1-4 alleles. Twenty alleles were obtained from females' genome samples and nineteen from males (Tables $3 \& 4$ ). The average of alleles per locus was 2.5 and 2.4 for females and males, respectively. It is worth mentioning that, the homozygous and heterozygous of locus do not depend on the sex. The dendrogram of SSR markers of males and females' samples are shown in Figs. ( 4 \& 5), respectively. The dendrograms classified the studied samples of males and females into two clusters with respect to the studied locations. The up and downstream drain samples were in a separated cluster in the two sexes.

The two dendrograms indicate the genetic variances in SSR loci of fish samples from the same sex in the different studied locations. Hashem et al. (2020a) deduced the same results when they used ISSR markers and indicated that those variances were in a positive association with the concentrations of heavy metals and the quality of up and downstream of the drain. The previous authors assumed that, the concentrations of heavy metals in downstream water cause DNA mutilation.

Fishes are impacted strongly by environmental pollution, and the fishes potential

to persist in contaminated water depends on their adaptive capacity, which is closely linked to their genome variability (Gross et al., 2010; Schneider et al., 2013; Silva et al., 2016; Araújo da Silva et al., 2019).

In the present examination, the SSR markers were used to identify any molecular effects of polluted water from the El-Rahawy Drain on the O. niloticus DNA. Compared to ISSR, the SSR markers are specific and highly polymorphic (Karp et al., 1997; Jones 
et al., 1997), but they require information of the DNA sequence for specific primers' design.
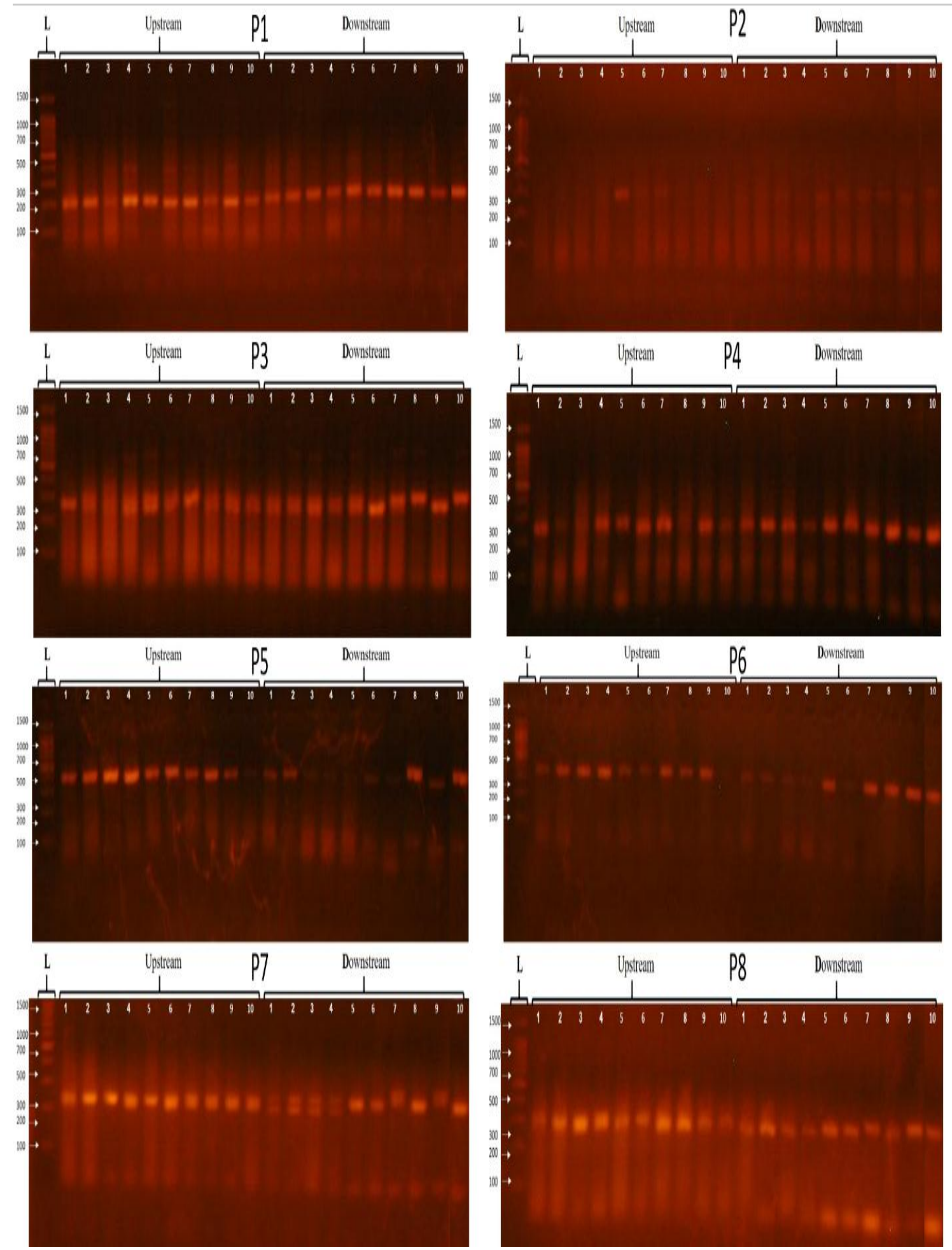

Fig. 3: Agarose Gel Electrophoresis for Amplified SSR Fragments Using (P1 - P8) Primers with Samples of the Two Different Locations of El-Rahawy Drain (Up and downstream).

Lines 1-5: males, Lines 6-10: Female, and L: DNA ladder. 
Table 3: The Obtained Fragments and 0/1 Table of the Eight SSR Primers that were Used with O. niloticus Males' Samples from Up and Downstream of the Studied Drain.

\begin{tabular}{|c|c|c|c|c|c|c|c|c|c|c|c|}
\hline \multirow{3}{*}{ Primers } & \multirow{3}{*}{ Alleles } & \multicolumn{10}{|c|}{ Males samples } \\
\hline & & \multicolumn{5}{|c|}{ Upstream } & \multicolumn{5}{|c|}{ Downstream } \\
\hline & & 1 & 2 & 3 & 4 & 5 & 1 & 2 & 3 & 4 & 5 \\
\hline \multirow{4}{*}{ P1 } & 1 & 0 & 0 & 0 & 0 & 0 & 0 & 0 & 1 & 1 & 1 \\
\hline & 2 & 0 & 0 & 0 & 0 & 0 & 1 & 1 & 0 & 0 & 0 \\
\hline & 3 & 0 & 0 & 0 & 1 & 1 & 0 & 0 & 0 & 0 & 0 \\
\hline & 4 & 1 & 1 & 1 & 1 & 1 & 0 & 0 & 0 & 0 & 0 \\
\hline P2 & 1 & 0 & 0 & 0 & 0 & 1 & 0 & 0 & 0 & 0 & 0 \\
\hline \multirow{2}{*}{ P3 } & 1 & 0 & 0 & 0 & 1 & 1 & 1 & 1 & 1 & 1 & 1 \\
\hline & 2 & 1 & 1 & 1 & 1 & 1 & 1 & 1 & 1 & 1 & 1 \\
\hline \multirow{2}{*}{ P4 } & 1 & 0 & 0 & 0 & 1 & 1 & 0 & 0 & 0 & 0 & 0 \\
\hline & 2 & 1 & 1 & 1 & 1 & 1 & 1 & 1 & 1 & 1 & 1 \\
\hline \multirow{2}{*}{ P5 } & 1 & 0 & 1 & 1 & 1 & 1 & 0 & 0 & 0 & 0 & 0 \\
\hline & 2 & 1 & 1 & 1 & 1 & 1 & 1 & 1 & 1 & 1 & 1 \\
\hline \multirow{3}{*}{ P6 } & 1 & 1 & 1 & 1 & 1 & 1 & 0 & 0 & 0 & 0 & 0 \\
\hline & 2 & 0 & 1 & 1 & 1 & 0 & 1 & 1 & 1 & 1 & 1 \\
\hline & 3 & 0 & 0 & 0 & 0 & 0 & 0 & 0 & 0 & 0 & 1 \\
\hline \multirow{3}{*}{ P7 } & 1 & 1 & 1 & 1 & 1 & 1 & 1 & 1 & 1 & 1 & 1 \\
\hline & 2 & 0 & 0 & 0 & 1 & 0 & 0 & 0 & 0 & 0 & 0 \\
\hline & 3 & 0 & 0 & 0 & 0 & 0 & 1 & 1 & 1 & 1 & 0 \\
\hline \multirow{2}{*}{ P8 } & 1 & 1 & 1 & 1 & 1 & 1 & 0 & 0 & 0 & 0 & 0 \\
\hline & 2 & 0 & 1 & 1 & 1 & 0 & 1 & 1 & 1 & 1 & 1 \\
\hline
\end{tabular}

Table 4: The Obtained Fragments and 0/1 Table of the Eight SSR Primers that were Used with O. niloticus Females' Samples from Up and Downstream of the Studied Drain.

\begin{tabular}{|c|c|c|c|c|c|c|c|c|c|c|c|}
\hline \multirow{3}{*}{ primers } & \multirow{3}{*}{ Alleles } & \multicolumn{10}{|c|}{ Females samples } \\
\hline & & \multicolumn{5}{|c|}{ Upstream } & \multicolumn{5}{|c|}{ Downstream } \\
\hline & & 1 & 2 & 3 & 4 & 5 & 1 & 2 & 3 & 4 & 5 \\
\hline \multirow{3}{*}{ P1 } & 1 & 0 & 0 & 0 & 0 & 0 & 1 & 1 & 1 & 1 & 1 \\
\hline & 2 & 0 & 0 & 0 & 0 & 0 & 1 & 1 & 1 & 1 & 1 \\
\hline & 3 & 1 & 1 & 1 & 1 & 1 & 0 & 0 & 0 & 0 & 0 \\
\hline P2 & 1 & 1 & 1 & 0 & 0 & 0 & 1 & 1 & 1 & 1 & 1 \\
\hline \multirow{3}{*}{$\mathbf{P 3}$} & 1 & 1 & 1 & 0 & 0 & 0 & 0 & 0 & 1 & 0 & 1 \\
\hline & 2 & 1 & 1 & 0 & 0 & 0 & 0 & 1 & 0 & 0 & 0 \\
\hline & 3 & 0 & 0 & 1 & 1 & 1 & 1 & 0 & 0 & 1 & 0 \\
\hline \multirow{2}{*}{$\mathbf{P 4}$} & 1 & 0 & 1 & 0 & 0 & 0 & 1 & 0 & 0 & 0 & 0 \\
\hline & 2 & 1 & 1 & 1 & 1 & 1 & 1 & 1 & 1 & 1 & 1 \\
\hline \multirow{2}{*}{ P5 } & 1 & 1 & 1 & 1 & 1 & 0 & 0 & 0 & 1 & 0 & 1 \\
\hline & 2 & 1 & 1 & 1 & 1 & 1 & 1 & 1 & 1 & 1 & 1 \\
\hline \multirow{4}{*}{ P6 } & 1 & 1 & 1 & 1 & 1 & 1 & 0 & 0 & 0 & 0 & 0 \\
\hline & 2 & 0 & 0 & 0 & 0 & 0 & 1 & 1 & 1 & 0 & 0 \\
\hline & 3 & 0 & 0 & 0 & 0 & 0 & 1 & 1 & 1 & 1 & 1 \\
\hline & 4 & 0 & 0 & 0 & 0 & 0 & 0 & 0 & 0 & 1 & 1 \\
\hline \multirow{3}{*}{ P7 } & 1 & 0 & 0 & 0 & 0 & 0 & 0 & 1 & 0 & 1 & 0 \\
\hline & 2 & 1 & 1 & 1 & 1 & 1 & 1 & 1 & 0 & 1 & 0 \\
\hline & 3 & 1 & 1 & 1 & 1 & 1 & 0 & 0 & 1 & 0 & 1 \\
\hline \multirow{2}{*}{ P8 } & 1 & 1 & 1 & 1 & 1 & 1 & 0 & 0 & 0 & 0 & 0 \\
\hline & 2 & 0 & 1 & 1 & 0 & 0 & 1 & 1 & 1 & 1 & 1 \\
\hline
\end{tabular}




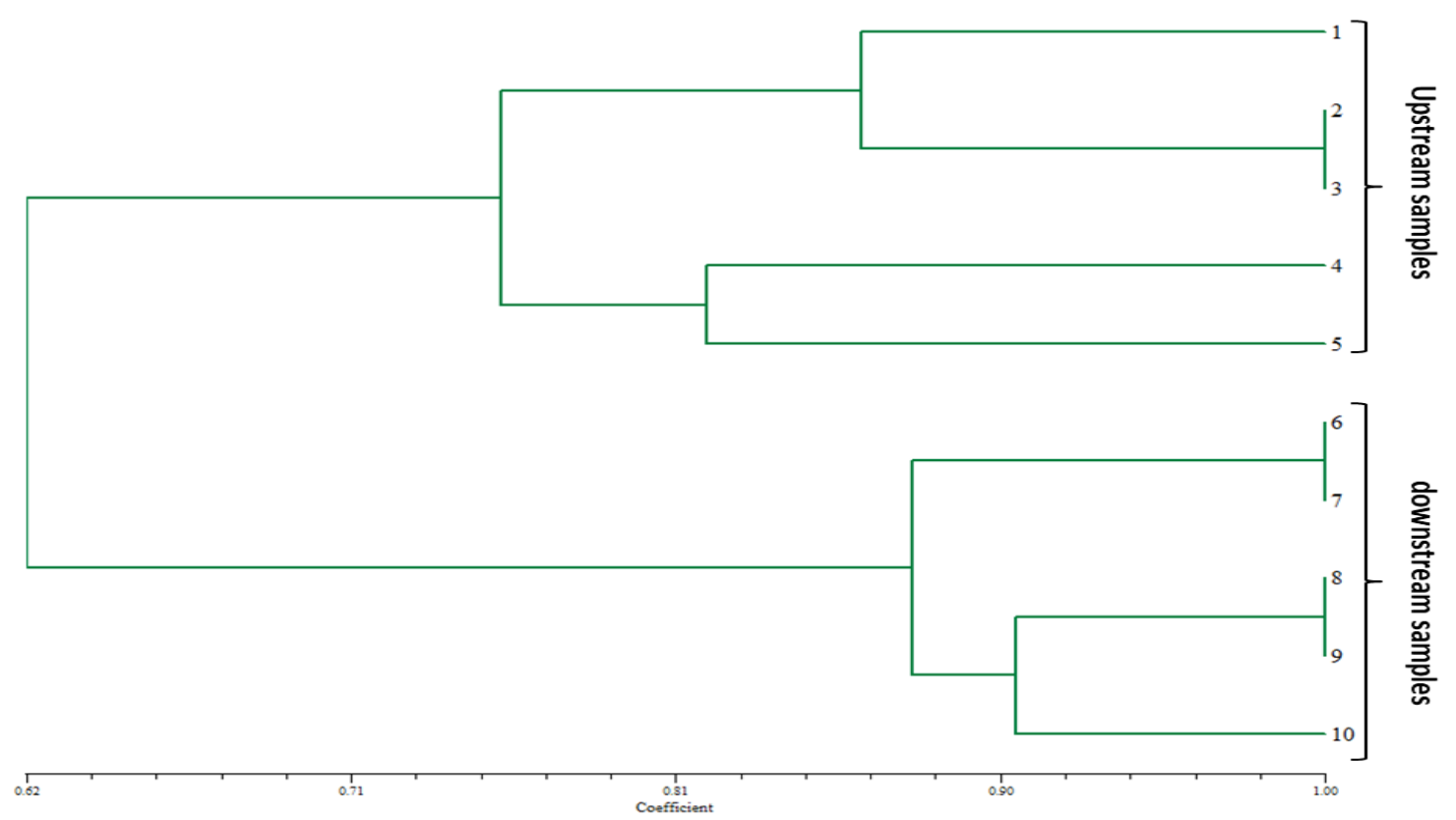

Fig. 4: The Dendrogram was Constructed from Eight Primers of SSR Markers Showing the Tilapia Males Samples' Genetic Relationships from Up and Downstream of ElRahawy Drain.

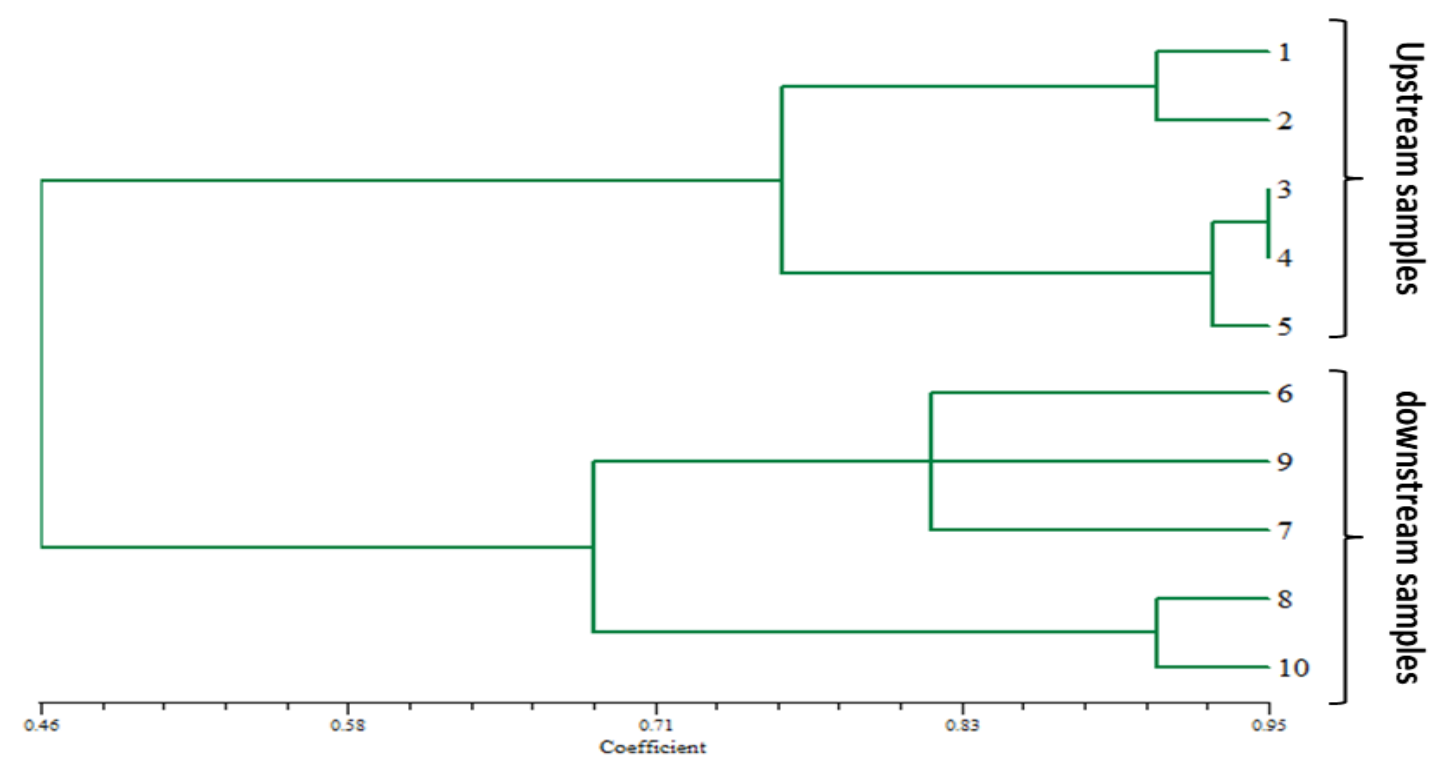

Fig. 5: The Dendrogram was Constructed from Eight Primers of SSR Markers Showing the Tilapia Females Samples' Genetic Relationships from Up and Downstream of ElRahawy Drain.

SSR marker is a co-dominant marker that can differentiate between heterozygotic and homozygotic samples and have a large number of alleles. Since the use of a single SSR marker cannot provide authentic information (Shehata et al., 2009), eight different SSR primers were used in the current study for the differences reliable detection between the fish samples from up and downstream El-Rahawy Drain. The 8 different SSR primers 
was recommended by Warburton et al. (2002) and Ravago-Gotanco et al. (2010). To eliminate any effects of the sex, the different samples SSR results of every sex (males or females) from the two locations were compared separately. In the samples of males and females, a number of unique fragments was found between the two locations samples.

Eminently, those unique fragments point to mutation occurrence. The mutations lead to the form of loss of a new primer binding site and the DNA fragment will hence be classified (disappearance or appearance) based on the effects of pollutants. It was noticed that, the downstream water of the studied drain was polluted with high concentrations of heavy metals compared to the upstream water; an observasion that concurs with that of Hashem et al. (2020a). To illustrate, Livingstone (2003), Sevcikova et al. (2011) and Kamollerd et al. (2019) stated that the pollutants including heavy metals can cause an imbalance between the free radical species production and reduction in fish. Additionally, the free radicals can attack DNA molecules, protein, and lipid to induce oxidative stress products and may cause DNA damage (Castano \& Becerril, 2004; Vilela et al., 2018; Kamollerd et al., 2019).

The genetic variations in fish samples from the same sex in different locations as observed from dendrograms of SSR results indicated a positive correlation with metals concentrations detected by Hashem $\boldsymbol{e t}$ al. (2020a) in the same studied area. The samples from the two different locations are separated into two different clusters as shown in Figs. (4 \& 5). The aforementioned results suggest that the pollutants in the downstream of ElRahawy Drain cause DNA damage. This finding matches with that of Wood et al. (2001), Vilela et al. (2018) and Kamollerd et al. (2019) who reported that, in the polluted water, heavy metal exposure could cause DNA damage in fish as double and strand single breakages, alterations in the mechanism of DNA repair and DNA-protein crosslinks. Heavy metals can induce oxidative stress, DNA damage, point mutations, and several other indirect genotoxic effects (Waalkes, 2003; Castano \& Becerril, 2004; Suhartono et al., 2013, Kamollerd et al., 2019).

\section{CONCLUSION}

As a result of the persistent discharge of water containing high concentrations of organic waste and salts from agricultural runoff of the El-Rahawy Drain, Rosetta Branch is suffering from severe pollution and consequently impacts the Nile aquatic life. The fish samples collected downstream of El-Rahawy displayed more extreme histopathological and genetic variations than those collected upstream. It is recommended to make a master plan for sewage treatment with an identified target in rural areas. Additionally, the awareness of people who live on the banks of the River Nile valley must be increased.

\section{REFERENCES}

Abdel-Satar, A.M.; Ali, M.H.H and Goher, M.E. (2017). Indices of water quality and metal pollution of Nile River, Egypt. Egyptian J. of Aquatic Research, 43: 21-29.

Ahmed, N.A.M. (2012). Biochemical studies on pollution of the River Nile at different stations of Delta barrage (Egypt). Ph.D. Thesis, fac. Agri., Benha Univ., Egypt. 
Ahmed, N.A.M.; Flefil, N.S.; Tayel, S.I.; Mahmoud, S.A. and Soliman, A. (2019). Biological treatment of ammonia using biofloc system for Oreochromis niloticus fish. Egyptian Journal of Aquatic Biology \& Fisheries Zoology Department, Faculty of Science, Ain Shams University, Cairo, Egypt. 23(4): 639 - 657.

Al-Afify, A.D.G. and Abdel-Satar, A.M. (2020): Risk assessment of heavy metal pollution in water, sediment and plants in the Nile River in the Cairo region, Egypt, Oceanological and Hydrobiological Studies 49 (1): 1-12.

Aly, S.M.; Zaki, M. and Genaidy, H. (2003). Pathological, biochemical, haematological and hormonal changes in catfish (Clarias gariepinus) exposed to lead pollution. Egypt. Vet. Med. Assoe, 63(1): 331-342.

Araújo da Silva, F.; Feldberg, E.; Moura Carvalho, N.D.; Hernández Range, S.M; Schneider, C.H; Carvalho-Zilse, G.A; Fonsêca da Silva, V.and Gross, M.C. (2019). Effects of environmental pollution on the rDNAomics of Amazonian fish. Environmental Pollution, V. 252, p. 180-187.

Bayomy, M.F.F. and Mahmoud, S.A. (2007). Some hematological and histological studies on Clarias gariepinus fish living in different sites of the River Nile in relation to water quality criteria. J. Egypt. Ger. Soc. Zool., (54c): 33-47.

Bayomy, M.F.F.; Elewa, A.A.; Tayel, S.I.; El-Kasheif, M.A. and El- Zeer M.E. (2017). Toxicological studies of water with a particular reference to its effect on Clarias gariepinus fish at El-Bahr El- Pharaony Drain, El-Menoufiya Governorate, Egypt. Journal of Bioscience and Applied Research, 3 (3): 265-272.

Begum, G. (2004). Cabofuran insecticide induced biochemical alterations in liver and muscle tissues of the fish Clarias batrachus (Linn.) and recovery response. Aquat. Toxicol., 66: 83-92.

Bernet, D.; Schmidt, H.; Meier, W.; Burkhardt-Olm, P. and Wahi, T. (1999). Histopathology in fish: Proposal for a protocol to assess aquatic pollution. J. fish Disease, 22: 25-34.

Beyer, J.; Sandvik, M.; Hylland, K.; Fjeld, E.; Egaas, E. et al. (1996). Contaminant accumulation and biomarker responses in flounder (Platichthys flesus L) and Atlantic cod (Gadus morhua L) exposed by caging to polluted sediments in Sorfjorden, Norway. Aquatic Toxicol 36: 75-98.

Bitten-Court, L.J.G.; Kreutz, L.C.; De Souza, C.; Rodrigues, L.B.; Fioreze, I. et al. (2003). Haematological Changes in Jundia (Rhamdies quelen) after acute and chronic stress caused by usual aquacultural management, with emphasis on immuno suppressive effects Aquaculture 237: 229-236.

Castano, A. and Becerril, C. (2004). In vitro assessment of DNA damage after short and long-term exposure to benzo (a) pyrene using RAPD and the RTG-2 fish cell line.Mutation Research 552: 141-151. 
Eshel, O.; Shirak, A.; Weller, J.I.; Hulata, G. and Ron, M. (2012). Linkage and Physical Mapping of Sex Region on LG23 of Nile Tilapia (Oreochromis niloticus). 3G genes genomes genetics Volume 2. January 2012. 35.

Ezeri, G.N.; Gabriel, U.U. and Opabunmi, O.O. (2004). Haematological response of cultured and wild Clarias gariepinus to acclimation. Environment and Ecology 22: 628632.

Gross, M.C.; Schneider, C.H.; Valente, G.T.; Porto, J.I.R.; Martins, C. and Feldberg, E. (2010). Comparative cytogenetic analysis of the genus symphysodon (DiscusFishes, Cichlidae): chromosomal characteristics of retrotransposons and minor ribosomal DNA. Cytogenet. Genome Res., 127 (1): 43-53.

Hashem, M.H.; Tayel, S.I.; Sabra, E.A.; Yacoub, A.M. and Heiba, A.A. (2020a). Impact of the water quality of El-Rahawy Drain on some genetic and histopathological aspects of Oreochromis niloticus. Egyptian Journal of Aquatic Biology and Fisheries 24 (2): 19-38.

Hashem, M.H.; Meshhal, D.T.; Mohamed, F.A.S. and Khamiss, O.A. (2020b). Establishment of a cell culture system and characterization of the primary cultures from different organs of the Nile tilapia Oreochromis niloticus. Egyptian Journal of Aquatic Biology and Fisheries 24 (4): 127-137.

Ibrahim, S.A. and Mahmoud, S.A. (2005). Effect of heavy metals accumulation on enzyme activity and histology in liver of some Nile fish in Egypt. J. Aquat. Biol. and Fish, 9 (1): 203-219.

Jones, C.J.; Edwards, K.J.; Castaglione, S.; Winfield, M.O.; Sale, C. Va Wiel; Bredemeijer, C.; Buianti, M.; Maestri, E.; Malcevshi, A.; Marmiroli, N.; Aert, R.; Volckaet, G.; Rueda, J.; Linacero, R.; Vazquez, A. and Karp, A. (1997). Reproducibility testing of RAPD, AFLP and SSR markers in plants by a network of European laboratories. Mol. Breed. 3: 381-390.

Kadry, S.M.; Tayel, S.I.; Afify, M.F.H. and El-Sayed, R.A. (2015). Ecohistopathological studied on Oreochromis niloticus fish living in Damietta Branch in Egypt. World J. Pharm. Sci., 3(5): 815-825.

Kamollerd, C.; Senaphan, K.; Tengjaroenkul, B.; Monkheang, P. and Neeratanaphan, L. (2019). Oxidative stress and genetic differentiation in experimental tilapia fish exposed to heavy metals in a reservoir near a municipal landfill. Applied Ecology and Environmental Research 17(6):12893-12907.

Karp, A.; Kresovich, S.; Bhat, K.V.; Ayada, W.G. and Hodgkin, T. (1997). Molecular tools in plant genetic resources conservation: a guide to the technologies. IPGRI Technical Bulletin No. 2. International Plant Genetic Resources Institute, Rome, Italy.

Livingstone, D. (2003). Oxidative stress in aquatic organism in relation to pollution and agriculture. - Revue de Medecine Veterinaire 154: 427-430. 
Mahmoud, S.A and El-Naggar, A.M. (2007). Alterations in Clarias gariepinus caused by pollutants at El-Rahawy area, Rosetta Branch, River Nile, Egypt. J. Egypt. Acad. Environ., Develop., 8(2): 61-70.

Mohamed M.Y.; Ghannam H.E. and Nasr Mohamed Ahmed N.M. (2020). Impact of Water Quality Changes on Hematological, Biochemical and Gonads Histology of Oreochromis Niloticus from Two Types of Water. The Egyptian Journal of Histology, 43 (4): 1177-1187.

Osman, A.G.M. (2012). Biomarkers in Nile tilapia Oreochromis niloticus niloticus (Linnaeus, 1758) to assess the impacts of river Nile pollution: bioaccumulation, biochemical and tissues biomarkers. J Environmental Protection 3: 966-977.

Othman, A.A.; Al-Afify, A.D.G.; Abdel-Satar, A.M. and Ramadan, M.F. (2020). Quality assessment of surface water using the Nile Chemical Pollution Index (NCPI) and microbiological pollution of the Rosetta Branch (Nile River, Egypt), African Journal of Aquatic Science 2020 46: 1-13.

Rashed, M.A.; Saad, Y.M.; Ibrahim, M.M. and El-Seoudy, A.A. (2008). Geneticstructure of Natural Egyptian Oreochromis niloticus evaluated from dominant DNA markers. Global Veterinaria, 2(2): 87 - 91.

Ravago-Gotanco, R.; Lumibao, C.Y. and Pante, Ma.J.R. (2010). Isolation and characterization of thirteen microsatellite markers for the rabbitfish, Siganus fuscescens, Conservation Genet Resour (2010) 2:225-227.

Reantaso, M.B. (2017). Tilapia Lake Virus (TiLV) Caused by an Orthomyxo-like virus (Family Orthomyxoviridae) Threatening Cultured and Wild Stocks of Tilapia. FAO Aquaculture Newsletter, 57: 9-11.

Rohlf FJ. (2000). On the use of shape spaces to compare morphometric method. Hystrix, Italian J. Mammology (n.s.), 11(1): 8-24.

Ruas, C.B.G.; Carvalho, C.D.; de Araujo, H.S.S.; Espindola, E.L.G. and Fernandes, M.N. (2008). Oxidative stress biomarkers of exposure in the blood of cichlid species from a metal-contaminated river. Ecotoxicol environment safety 71: 86-93.

Saad, S.M.M.; El- Deeb, A.E.; Tayel, S.I.; Al-Sheri, E. and Ahmed, N.A.M. (2012). Effect of heavy metals pollution on histopathological alterations in muscles of Clarias gariepinus inhabiting the Rosetta Branch, River Nile, Egypt. Animal Biotechnology, pp. 79-88.

Saad, Y.M.; Mansour, A.A. and EL-Nagar, A.M. (2009). Monitoring of genetic polymorphism in some tilapia species based on fin tissues isozyme distributions. World J. Zool., 4(1): $24-28$.

Sadauskas-Henrique, H.; Sakuragui, M.M.; Paulino, M.G. and Fernandes, M.N. (2011). Using condition factor and blood variable biomarkers in fish to assess water quality. Environmental Monitoring and Assessment 181(1-4): 29-42. 
Schneider, C.H.; Gross, M.C.; Terencio, M.L.; Do Carmo, E.J.; Martins, C. and Feldberg, E. (2013). Evolutionary dynamics of retrotransposable elements Rex 1, Rex 3 and Rex 6 in neotropical cichlid genomes. BMC Evol. Biol. 13, 152.

Seriani, R.; Abessa, D.M.S.; Kirschbaum, A.A.; Pereira, C.D.S.; Romano, P. et al. (2011). Relationship between water toxicity and hematological changes on Oreochromis niloticus. Brazilian J Aquatic Sci Technol 15: 47-53.

Sevcikova, M.; Modra, H.; Slaninova, A. and Svobodova, Z. (2011). Metals as a cause of oxidative stress in fish: a review. Veterinarni Medicina, 56: 537-546.

Shehata, A.I.; Al-Ghethar, H.A. and Al-Homaidan, A.A. (2009). Application of simple sequence repeat (SSR) markers for molecular diversity and heterozygosity analysis in maize inbred lines. Saudi J Biol Sci. 2009 Oct; 16(2): 57-62.

Silva, F.A.; Schneider, C.H.; Feldberg, E.; Baccaro, F.B.; Carvalho, N.D.M. and Gross, M.C. (2016). Genomic organization under different environmental conditions: Hoplosternum littorale as a model. Zebrafish 13 (3): 197e208.

Suhartono, E.; Triawanti; Yunanto, A.; Firdaus, R.T. and Iskandar (2013). Chronic cadmium hepatooxidative in rats: treatment with haruan fish (Channa striata) extract. APCBEE Procedia 5: 441-445.

Tayel, S.I. (2008). Histological and biochemical seasonal changes of Oreochromis niloticus muscles in relation to water quality at Zefta and El-Mansoura Cities, Damietta branch River Nile, Egypt. J. Egypt. Acad. Soc. Environ. Develop., 8(2):81-92.

Tayel, S.I.; Ibrahim, S.A. and Mahmoud, S.A. (2013). Histopathological and muscle composition studies on tilapia zillii in relation to water quality of lake Qarun, Egypt, J. Appl. Sci. Res., 9(6) : 3857-3872.

Tayel, S.I.; Ahmed, N.A.M. and EL-Hossiny, M.A. (2014). Impact of diffused pollution on histological and hematological properties of Mugil cephalus and Mugil capito collected from Lake Manzalah, Egypt. Inter. J. Environ. Sci. \& Engin. 5:51-67.

Tayel, S.I.; Mahmoud, S. A.; Ahmed, N. A. M. and Abdel Rahman A.S.A. (2018). Pathological impacts of environmental toxins on Oreochromis niloticus fish inhabiting the water of Damietta branch of the River Nile, Egypt. Egypt. J. Aqua. Biol. \& Fish., 22 (5): 309- 321.

Tayel, S.I.; Ahmed, M.N. and Ramadan, E.A. (2020). Histopathological alterations and parasitic infection in Oreochromis niloticus fish inhabiting the River Nile water. Egypt. J. Aqua. Biol. \& Fish., 24(1): 233-247.

Vilela, C.L.S.; Bassin, J.P. and Peixoto, R.S. (2018). Water contamination by endocrine disruptors: Impacts, microbiological aspects and trends for environmental protection. Environmental Pollution 235: 546-559.

Waalkes, M.P. (2003). Cadmium carcinogenesis. Mutation Research, 533: 107-120.

Warburton, M.L.; Zianchun, X.; Crossa, J.; Frnaco, J.; Melchinger, A.E.; Frisch, M.; Bohn, M. and Hoisington, D. (2002). Genetic characterization of CIMMYT inbred maize 
lines and open pollinated populations using large scale fingerprinting methods. Crop Sci. 42, 1832-1840.

Wood, R.D.; Mitchell, M.; Srouros, J. and Lindahi, T. (2001). Human DNA repair genes. Science 291: 1284-1289.

Yacoub, A.M.; Mahmoud, S.A. and Abdel-Satar, A.M. (2021). Accumulation of heavy metals in tilapia fish species and related histopathological changes in muscles, gills and liver of Oreochromis niloticus occurring in the area of Qahr El-Bahr, Lake AlManzalah, Egypt, Oceanological and Hydrobiological Studies 50(1): 1-15. DOI: 10.1515/ohs-2021-0000. 